\title{
Oorspronklikheid en verwante begrippe by N.P. van Wyk Louw
}

\author{
H.J. Schutte \\ Departement Afrikaans \\ Universiteit van Suid-Afrika \\ PRETORIA
}

\begin{abstract}
Originality and related concepts in N.P. van Wyk Louw's work

This article investigates N.P. van Wyk Louw's confrontation with originality and related concepts. Throughout his writing career, especially in his essays and public lectures, he attempted to clarify originality as "one of the most difficult concepts in literature". An outstanding feature of his research is that he repeatedly distanced himself from the Romantic view of the concept of originality. In stressing the importance of tradition he criticized the concept of "make it new" by substituting it with "acknowledged forms" from which a writer could work. The sole criterion is to ask whether a work of art is "good" and not whether it is "new". Van Wyk Louw's view of originality is closely related to intertextuality, but in contrast to many postmodernists, the "text" is of crucial importance to him. In the domain of literature one would say that Van Wyk Louw's view of originality positions him essentially in line with the Esthetics of Identity.
\end{abstract}

\section{Inleidend}

Die besinning oor begrippe soos beïnvloeding en oorspronklikheid het Van Wyk Louw bykans deur sy hele skrywersloopbaan besig gehou. Moontlik as die eerste bewys daarvan is dié inskrywing in 'n aantekeningboek van 1938-1939 (kyk 2.X.7.5):!

1 Die gebruik van 'n kodenommer, soos "2.X.7.5", verwys na die vindplek van 'n dokument uit die N.P. van Wyk Louw-versameling in die Dokumentasiesentrum van die Universiteit van Stellenbosch. Die afkortings Vers. pr. 1 en Vers. pr. 2 in die loop van die bespreking verwys na Versamelde prosa $l$ en Versamelde prosa 2 van Van Wyk Louw (1986). 
Qor beinvloeding: ooreenstemming + verskille.

Tussen die skrywers (en onder ander kunstenaars) van ' $n$ tydperk is daar 'n fundamentele ooreenstemming en fundamentele verskille. Soos tussen Beethoven, Haydn, Schumann en Ravel, Stravinsky, ens.; Boutens, Leopold, Bloem - Kloos, Verwey.

Daardie ooreenstemming is die maklikste om raak te sien; en dit is ál wat nog by ons jongeres bestudeer is. Die fyner aanvoeling van die verskille ontbreek ten enemale. En dié is nog groter as gewoonlik tussen tydgenote.

In die tweede paragraaf is daar 'n irritasie by die jong digter oor die behandeling van sy generasie vanweë die simplistiese wyse waarvolgens "beïnvloeding" vertolk is. Hoe kontrasteer dit nie met die ontspanne benadering van die gevestigde skrywer van 1963 in die Standpunte-artikel "'Vernuwing' en 'gehalte" (Louw, 1963:27-33). Die verbasing word hier eufemisties te kenne gegee asof hy nog nooit grondig nagedink het nie oor die gebruik van "vernuwing" as evaluatiewe begrip soos dit saamhang met "oorspronklikheid": "Ek verbeel my selfs ek het êrens al oor oorspronklikheid en my minagting vir blote oorspronklikheid gepraat" (Vers. pr. 2, p. 175). ${ }^{2}$

Wat was Van Wyk Louw se opvatting van oorspronklikheid? Toon sy beskouing daaroor in die loop van byna drie dekades 'n bepaalde ontwikkeling? Vir die beantwoording van hierdie vrae is "Ars poetica" 'n sentrale gedig om te bestudeer. Vir die leser wat die inset ("Uit die gevormde literatuur / is nooit weer poësie te maak nie") bloot op die woord af beoordeel, mag dit voorkom of die beginsel van intertekstualiteit in "Ars poetica" weerspreek word - ondanks die feit dat Tristia (1962) by uitstek 'n samespel van tekste is (vgl. Hambidge, 1989:57). So beskou, lyk dit ook of die beginsel van oorspronklikheid voorgehou word. En "oorspronklikheid" beteken dan hier "nuut" - iets wat nie verband hou met voorafgaande dinge nie. Is dit egter 'n aanneemlike interpretasie van "Ars poetica" én het Louw so oor oorspronklikheid gedink? Alvorens dus beslis kan word of Louw intertekstualiteit ontken - en indien nie, hoe hy aansluit by die hedendaagse opvatting van intertekstualiteit - sal eers noukeurig nagegaan moet word hoe hy in die loop van jare besin het oor begrippe soos oorspronklikheid, beïnvloeding en plagiaat. Die ondersoek hiervan verloop soos volg:

2 Hierdie artikel wat Louw se reaksie was op kritiek oor Vernuwing in die prosa (1961), is sedert die tweede druk van hierdie boek as voorlaaste hoofstuk bygevoeg. As sodanig is dit 'n voorbeeld van Louw se voortgesette besinning oor corspronklikheid en verwante begrippe. 
* Van Wyk Louw se besinning oor oorspronklikheid en verwante begrippe.

* Van Wyk Louw se verklaring van hierdie begrippe.

* Die plasing van Van Wyk Louw se opvatting van oorspronklikheid binne teorieë van literatuurontwikkeling en die vraag of/hoe Louw inskakel by die hedendaagse begrip van intertekstualiteit.

\section{Besinning oor oorspronklikheid en verwante begrippe}

\subsection{Bronneverwysings}

In sy verheldering van begrippe soos beïnvloeding en oorspronklikheid het Louw aangesluit by bepaalde literêre studies daaroor. Vanweë die essayistiese aard van sy besinning word bronne egter selde vermeld. Slegs by uitsondering is ' $n$ bron pertinent onder die aandag gebring. In hierdie verband dink 'n mens aan die 1951-essay "Begrip 'oorspronklikheid"" (Vers. pr. 2, p. 24-27) waarin deur middel van 'n voetnoot gewys is op Logan Pearsall Smith se Four words: Romantic, originality, creative, genius. Hoe hoog Louw hierdie studie aangeslaan het, word duidelik uit 'n ongepubliseerde lesing van 1951, "Oorspronklikheid as literêre begrip" (2.To.22, p. 3a), waar hy dit as "('n) Briljante boekwerkie" bestempel.

Spesifieke bronneverwysings waarmee Louw die verkeerde gebruik van oorspronklikheid wou onderstreep, is afkomstig van klassici - eerstens woorde van T.A. Sinclair in $A$ history of classical Greek literature om te bewys dat óók Homerus aansluiting moes gevind het by 'n voorafgaande tradisie:

The Illiad and the Odyssey are perfect and finished productions ... which no genius however great could have composed if he had not had behind him a long tradition of literary development. The Greeks themselves knew that there was literature before Homer, but they tell us little ... (vgl. Vers. pr. 1, p. 394).

En binne die Griekse drama is Gilbert Murray in 'n ongepubliseerde 1941-stuk (2.X.13.5, p. 76) ook met instemming aangehaal: "And as for the Persae being largely modelled on a previous play by another writer, that, one might almost say, is the normal condition of most great poetry" (Gilbert Murray: Aeschylus, 124).

In die ongepubliseerde stukke is plek-plek erkenning verleen aan eietydse Afrikaanse studies waarby Louw in sy beskouing aangesluit het. Van belang is drie name waarmee hy telkens sy instemming te kenne gegee het van hoe 'n studie van beïnvloeding behoort te wees - slegs aangedui as "Prof. Dekker"/ "Dekker", "Mulder" en "W.E.G. Louw"/“"Gladstone". Met hierdie kriptiese 
inskrywings is verwys na die 1926-proefskrif van G. Dekker: Die invloed van Keats en Shelley in Nederland gedurende die negentiende eeu; die 1937Jaarboek-artikel van H.A. Mulder: "Oor invloed in die literatuur"; en die 1942-proefskrif van W.E.G. Louw: Die invloed van Gorter op Leopold.

Dit was veral die proefskrif van Dekker wat vir Van Wyk Louw rigtinggewend was. Tydens 'n 1957-huldigingstoespraak oor Radio Hilversum (postuum gepubliseer in Weegskaal, 1982; vgl. Vers. pr. 2, p. 551-552) het Louw hom só daaroor uitgelaat: "Sal ek vertel hoe ek as student hierdie werk verslind het? ... In die ontsettende moeilike tema van beïnvloeding in die literatuur, in die wêreld van die gees, word te dikwels deur 'fools' inge-'rush' waar 'angels fear tot tread". . Hy haal twee passasies aan waarby hy die volgende geskryf het: “... ek onthou weer nie wanneer nie: 'Mooi' met twee uitroeptekens agterna".

... diepgaande literêre invloed moet ons nie beskou as 'n natuurkundige mengingsproses, waarby die noukeurige ondersoeker die vermengde stowwe later weer kan terugvind nie ... Dis veel eer 'n chemiese reaksie, waarby, met geweldige ontbranding en bruising baiemaal, uit 'n gegewe vaste, inaktiewe verbinding elemente, wat daar reeds in is, vry gemaak en tot daadwerklike aksie in staat gestel word.

Die werklike diepgaande invloed is dié wat berus op 'n vervulling van behoeftes en waarvan later die spore weggewis is.

Louw het ook na kunstenaars verwys. In sy beroep op kunstenaars wat hulle nie gesteur het aan oorspronklikheid nie, het een naam uitgetroon: Shakespeare. Hierdie dramaturg was vir hom dié model, waarmee hy wou bewys dat die betreklik moderne opvatting "van die afgelope 150 of 200 jaar" (2.To.22, p. 1) oor oorspronklikheid verkeerd is. Op hierdie naam kom Louw telkens terug. So word in 'n 1951-lesing (2.To.22, p. 2 \& 3) na "Shakespeare se soewereine glimlag!" verwys vanweë "sy onbekommerdheid, onverskilligheid oor oorspronklikheid". Hoe radikaal Louw hier kon dink, blyk byvoorbeeld uit dié opmerking op p. 13 van hierdie lesing: "Selfs alle plagiaat word oorspronklik wanneer dit groot aangewend word. Daarom gaan Shakespeare vry uit!" (VWL se beklemtoning). Waarop dit vir Louw hier neergekom het, is dat 'n groot kunstenaar se werk so ryk is aan bedoeling dat dit haas onuitputbaar is. Dit laat hom hierdie opmerking maak na aanleiding van Gundolf se Shakespeare in Deutschland: "Wys op Gundolf se groot Shakespeare-studie waarin hy aantoon hoe die 'invloed' van 'n groot figuur in elke eeu anders is" (2.X.13.5, p. 76).

Met betrekking tot eietydse literatuur het Louw verwys na Eliot se Waste land in die lesing "Oorspronklikheid as literêre begrip" (2.To.22, p. 10). Vergelyk die kursoriese opmerking: "Oorspronklikheid is juis die skep van 'n nuwe 
totaliteit. Waste land: 1.35 skrywers: ontleen, geparodieer; 2.6 tale Sanskrit; 3. op een boek gebaseer. Tog is dit een van die oorspronklikste." Maar ondanks sy lof vir Eliot as digter word hierdie skrywer as kritikus in die stuk "Navolging, beïnvloeding, oorspronklikheid" (2.AS.0.4, p. 2) gekapittel omdat hy "oorspronklikheid" as strewe na vernuwing te sterk vooropgestel het:

'Make it new' (Ezra Pound? of W. Lewis?) was nog nooit die leuse van die grootste skeppendes nie. Die meeste van hulle was gewillig om die erkende vorms van hul tyd te aanvaar en dié dan met hul eie ryk lewe te vul.

Vandaar die skeiding (tereg) tussen 'die skeppendes' en 'die vernuwers'. Die vernuwer kán wel 'n groot kunstenaar wees, maar hy was dit nog selde; studie van tegnieke kan later so fassinerend word dat die 'inhoud', die ryk lewe daarby vergeet raak; of 'n man (soos Gorter) wat tegelyk eksperimenteerder en skepper is, keer hom later van die eksperimentele af en gebruik hoogstens 'n paar 'verowerings' daarvan om sy eie werk te verryk.

T.S. Eliot wat self baie treffende dinge oor die 'Tradisie' in die literatuur gesê het, probeer m.i. te veel 'oorspronklik' (in die subjektivistiese sin) wees in die kritiek. Hy probeer telkens 'n totaal nuwe perspektief in die literatuurgeskiedenis bring.

\subsection{Aard en omvang van die studies}

Tristia (1962) is van meet af aan aangebied as 'n "geleerde" digbundel deur sy hiperbewuste werkwyse van ontlening en aansluiting by kultuurstrominge uit die verlede ("Wat? Speel hy ballinkie in Pontus? / dit wil die Latiniste weet"). Selfs in 'n "oop" digbundel soos Die halwe kring (1937) is Duitse invloede verwerk (vgl. Rosteutcher, 1941:115-122 en Hesse, 1953:17-41). Dit dui al daarop dat die blootstelling aan invloede skering en inslag vorm in Louw se werke. Tot die irritasie van die digter is sekere invloede soms verkeerdelik uitgewys, soos dat aspekte van die poësie uit Alleenspraak deur Leopold en Boutens beïnvloed is (kyk Kannemeyer, 1990:39-41 \& 91). Mede as gevolg hiervan was dit die impuls vir sy voortgesette besinning oor oorspronklikheid en verwante begrippe, want hoe dikwels was die skrywer nie die prooi van die kritikus se "jag op invloede" nie (vgl. Mulder, 1937:58 \& 63).

Hoe belangrik die opheldering van oorspronklikheid as literêre begrip vir Louw was, kan geillustreer word deur die voorrang wat hy dikwels self daaraan toegeken het, byvoorbeeld soos blyk uit sy aansoek van 6 Oktober 1957 om die hoogleraarskap in die Departement Afrikaans en Nederlands aan die Universiteit van die Witwatersrand (2.K.2.68.10). Van die "heelwat buitelesings in Nederland en Belgiê" is "slegs die rede voor die Koninklijke Vlaamsche Academie Oor die begrip 'Oorspronklikheid' in die Literatuur" 
(gehou op 28 Oktober 1951) vermeld, gevolg deur nog een ander rede. En met verwysing na navorsingswerk oor "ander temas waaraan ek gewerk het en waarvan die resultaat gedeeltelik gepubliseer is", staan "die begrip 'oorspronklikheid' en verwante begrippe in die literatuur" derde in volgorde (en rangorde?) van agt temas.

Dat daar vanuit akademiese geledere belangstelling was vir Louw se besinning oor die begrip oorspronklikheid, blyk uit die brief van 12 Desember 1951 deur die Sekretaris van die Koninklijke Vlaamse Academie (kyk 2.K.2.64). Die referent word versoek om die teks van sy "belangwekkende lezing" (in die paragraaf hierbo vermeld) so spoedig moontlik te besorg vir publikasie in die reeks Verslagen en mededelingen. Dat Louw besluit het om dit nie aan te stuur nie - wat meegebring het dat dit uiteindelik nie gepubliseer is nie (kyk Rombauts \& Hoebeke, 1986) - kan aan verskeie redes toegeskryf word. Hierdie lesing, getitel "Oorspronklikheid as literêre begrip" (2.To.22), was in 'n groot mate 'n samevatting van wat Louw reeds oor hierdie saak gepubliseer het of besig was om te publiseer. Daar is byvoorbeeld op p. 4-5 ruim (selfs woordeliks) gebruik gemaak van sy Standpunte-essay van Desember 1945 (reeks 1, deel 1, p. 70-72), "Cahiers van 'n kritikus" (Vers. pr. 1, p. 393-395). Verder herinner die bewoording en siening in hierdie lesing in meer as een opsig aan "Die oop gesprek"-essay in Die Huisgenoot van 30 Junie 1951. ${ }^{3}$

Dit was juis in die tyd van die 1951-lesing dat Van Wyk Louw telkens in "Die oop gesprek"-reeks oor een of ander aspek van die begrip oorspronkhikheid

3 In hierdie essay "'Oorspronklikheid" in die kuns" (Vers. pr. 2, p. 20-23) verwys Louw na die "soort aanbidding van 'oorspronklikheid"' as die hulde wat aan "'n byna kinderlike godinnetjie" gebring word. Hierdie voorstelling is deur middel van ' $n$ ander beeld, dié van ' $n$ keiser, in die inleidingsparagrawe van die 1951lesing soos volg uitgewerk:

"Daar kan geen twyfel aan bestaan nie dat in die afgelope 150 of 200 jaar die begrip 'Oorspronklikheid' 'n heersende vors - indien nie 'n oorheersende keiser - in die wye ryk van die kunste geword het. Byna iedereen bring hulde aan hom; en by weiniges kom dit óp om die regsgrond van sy gesag te ondersoek - veel minder dan, om die gesag van die nuwe vors te betwis!"

"En dat hierdie jong heerskappy van die 'Oorspronklikheid' skaars 'n eeu of twee tel, teenoor die tientalle eeue waarin sy eerwaardige voorgangers geheers het - voorgangers soos Tradisie, gesag, konvensie - ... hierdie jeugdigheid bring geen matiging in die aansprake van die jong vors, of in die verering wat sy aanhangers vir hom het nie." 
besin het. So was daar op 16 en 23 November 1951 die essay "Vir 'n jong digter: Oor baie lees" (Vers. pr. 2, p. 541-547), wat opgevolg is op 7 Desember 1951 met "Begrip 'oorspronklikheid"' (Vers. pr. 2, p. 24-27) en wat op 14 Desember 1951 (Die Huisgenoot, p. 19) afgesluit is met "Klein debat oor oorspronklikheid".

Hoewel Van Wyk Louw in 1951 intensief oor oorspronklikheid besin het, het hy al jare tevore daarmee begin. Uit aantekeningboeke vanuit die jare veertig blyk dit dat hy van tyd tot tyd sy gedagtes oor oorspronklikheid neergeskryf het moontlik met die oog op latere verwerking. So byvoorbeeld was die essay "Vir 'n jong digter: Oor baie lees", met die raad wat aan die jong digter gegee word om "wyd te lees" en hom "geestelik wyer oop te stel aan alle winde van die wêreld", reeds in knopvorm aanwesig in die Stellenbosch-lesing van $26 \mathrm{Mei}$ 1944 (2.To.14, p. 24). So word ook op p. 13-15 van hierdie essay aan die "jong skrywer" wat oorspronklik wil wees, onder meer dié raad gegee: "moenie ophou lees nie / gaan na die grootstes ... / gaan na alle tye ..." - alles idees wat neerslag gevind het in die latere essay.

In die lesings lyk dit of Van Wyk Louw die wye studieveld van oorspronklikheid wou dek, terwyl hy in die essay-aflewerings die geleentheid te baat geneem het om op één aspek te konsentreer en dit bevredigend af te handel. In die Vlaamse Akademie-lesing van 1951 is byvoorbeeld 'n verskeidenheid aspekte aan die orde gestel. Dat sommige van hierdie aspekte nog nie heeltemal verwerk is nie, blyk dan ook uit hierdie lesing, byvoorbeeld die kort uiteensetting van hoe oorspronklikheid binne die struktuur van 'n "literêre kunswerk" ondersoek behoort te word by wyse van die fonetiese, ritmiese, semantiese, logiese en metafisiese lae (vgl. 2.To.22, p. 11-14). Hierdie belangrike aspek het by die neerstip van enkele insigte gebly. Dit geld ook vir die aanduiding van verwante begripppe rondom oorspronklikheid, wat Louw soos volg onder mekaar neergeskryf het: "ontleding, navolging, epigonisme, beïnvloeding, plagiaat, parodie, vertaling, verwerking, stylsoort, tydstyl, generasiestyl, genre, tradisie, konvensie, cliché" (kyk p. 9). Later, in 'n aantekeningboek van 1957 (2.X.51, p. 15), brei hy die lys "literêre verwantskapsterme; grade van oorspronklikheid" uit deur nog die volgende te betrek: “"gemeenskaplike bron', pastiche, aanhaling, toevallige ooreenstemming, 'nagevolg' van, 'verwysing', 'eggo', 'geykte beeldspraak' en 'holruggeryde beeldspraak"".

Tot 'n afgeronde aanbieding van oorspronklikheid en verwante begrippe het Louw egter nooit gekon nie. Vanweë die voorlopige aard van die twee aanbiedingsmetodes wat hy gevolg het, die lesing- en essayvorm, sou dit waarskynlik ook nie maklik kon gebeur het nie. Hierdeur is wel van tyd tot tyd, "volgens die eis van omstandighede", verdere insigte na vore gebring in sy 
poging tot verklaring van hierdie begrippe en hoe hulle met mekaar saamhang. Interessant genoeg is sy verkenning van die aspek van "verwysing" in sy 1958intreerede, "Oor moeilike literatuur: die "verwysingsmoeilikheid"" (Vers. pr. 2, p. 400-413), nie in verband gesien met oorspronklikheid nie maar met die oorsake waarom literatuur as moeilik deur die leser ervaar word. By ander geleenthede, soos in die 1964-inleiding tot Windroos, "By ons jongste prosa" (vgl. Vers. pr. 2, p. 517-524), gaan Louw wel weer vóórt met sy beskouing oor en verheldering van begrippe soos vernuwing en navolging - waarmee moontlik 'n aksentverskuiwing in sy opvatting van oorspronklikheid (kyk slot van afdeling 4.1 hieronder).

Hoewel 'n mens by Louw dus nie moet soek na 'n breed opgesette studie wat oorspronklikheid en ander begrippe deurtastend ten opsigte van al die verskillende aspekte sou kon verklaar nie, gee hy in sy ontleding van 'n aantal aspekte in die essays en lesings wel 'n samehangende verklaring van enkele kernbegrippe.

\section{Verheldering en opvatting van kernbegrippe}

In die plek van die Romantiese opvatting van oorspronklikheid wat verklaar dat dit "nuut" beteken, stel Louw sy opvatting van oorspronklikheid wat hy in verband sien met die begrip tradisie. Wat dit alles behels, word in afdeling 3.1 bespreek.

Louw se afkeer van die Romantiese opvatting van oorspronklikheid het implikasies vir die begrip plagiaat. "Plagiaat" beteken "die oorneem van gedagtes, argumente, ens., uit 'n ander skrywer se werk en dit as jou eie laat deurgaan" (HAT). In sy teoretisering daaroor kom dit voor asof Louw die konsekwensies van letterdiefstal wil ignoreer - solank dit maar "groot aangewend word"! Met verwysing na Shakespeare "wat in sy kort lewe gegryp het na alles wat in sy hande kom" (Vers. pr. 2, p. 26-27)), haal Louw Pope met instemming aan. Pope het Shakespeare naamlik as dié voorbeeld van oorspronklikheid voorgehou: "If ever any Author deserved the name of Original, it was Shakespeare." In die praktyk is die saak van plagiaat egter nie so eenvoudig nie - selfs nie eers vir Louw nie. In afdeling 3.2 word kortliks daarna gekyk.

Die kriterium "om goed te skryf" binne Louw se opvatting van oorspronklikheid word in paragraaf 3.3 behandel. Die bespreking daarvan vind plaas aan die hand van Van Wyk Louw se gedig "Ars poetica". 


\subsection{Belang van die tradisie}

$\mathrm{Na}$ aanleiding van sy Stellenbosch-lesing van 26 Mei 1944 (2.To.14) skryf Van Wyk Louw in 'n brief van 16 Augustus 1944 aan Jan Greshoff:

... Die hooftema was: die noodsaaklikheid van 'n tradisie in die literatuur; titel: Navolging en Oorspronklikheid; inhoud: dat die hele literatuur één web is ... trek jy êrens aan 'n draad, dan roer dit daar ver in ' $n$ ander hoek ...

Hiervolgens is dit duidelik dat Louw se besinning oor "oorspronklikheid" in samehang met "tradisie" plaasgevind het. Sy besinning daaroor in die vroeë veertigerjare het eindelik uitgeloop op 'n vyftal essays oor tradisie binne die Suid-Afrikaanse verband. Hierdie essays is geskryf in "Die oop gesprek"-reeks gedurende 1951-1952: "Uithoek en middelpunt", "Geestelike bloedsomloop", "Lewe uit 'n tradisie", "Helde" en "Die web" (Vers. pr. I, p. 411-418 en 423449). Ongelukkig word daar in hierdie essays nie vermeld hoe sy opvatting van oorspronklikheid direk aansluit by sy opvatting van tradisie nie. ${ }^{4}$ Boonop lê die vyf 1951-essays oor oorspronklikheid verspreid van mekaar. Twee van hierdie essays is opgeneem in Maskers van die erns (1955) (Vers. pr. 2, p. 20-27), wat in hierdie bundel loshang tussen die ander essays met hul verskeidenheid van temadekking. Die essay "Vir 'n jong digter: Oor baie lees" is eers in 1982 in die postume Weegskaal opgeneem (vgl. Vers. pr. 2, p. 541-547). Die laaste essay, "Klein debat oor oorspronklikheid" (Die Huisgenoot, 14 Desember 1951) - klaarblyklik bedoel as toetssteen waarmee Louw sy opvatting oor oorspronklikheid in die voorafgaande essays krities beoordeel - het tot op hede nog nie in boekvorm verskyn nie. Hierdie onbevredigende toedrag bring mee dat die samehang van oorspronklikheid met die begrip tradisie misgekyk kan word.

Die direkte verband tussen die twee begrippe is reeds duidelik te sien in die kort Standpunte-"aantekening" van 1945, naamlik "Cahiers van 'n kritikus" (Vers. pr. 1, p. 393-395), waarin 'n ekskursie met "oorspronklikheid" en "beïnvloeding" onderneem word. Daar word vanaf Leopold tot by Homerus en selfs verder terug oor 25 eeue heen, deur vyf Westerse literature, 'n lyn aangetoon. Hierop stel Louw dan die volgende vrae: "(Wie) is 'oorspronklik'? Wie is 'navolgers'?" Dit is egter verkeerde vrae om te stel. Wat so 'n ondersoek aan die lig bring, is dat "die draad wat ons gevolg het", ons eindelik bring by die "oorspronge". En onder "oorspronge" moet nie "nuutheid" verstaan word nie soos "oorspronklikheid" sedert die Romantiek as waardebegrip vertolk is (vgl. ook Vers. pr. 2, p. 20, 22 \& 27). Deur die studie van "invloede", wat

4 Dié gelyktydige ontwikkeling is duidelik te sien in 'n 1940-aantekeningboek (2.X.11.1) met die besinning oor die onderwerp "Suid-Afrika - Europa. Kulturele verhoudinge". 
"ontsettende eise aan 'n navorser (stel)", kry ons 'n aanduiding van die "totaliteit van alle moontlike 'patrone van beïnvloeding' (wat) tesame die groot geheel wat ons die 'Westerse literatuur' noem, (vorm)". Vir die bewuswording van hierdie "patrone van beïnvloeding" wat die ondersoeker lei na "oorspronge", gebruik Louw die beeld van die web: "Waar 'n mens ook trek, die hele web roer."

Die beeld van die web gebruik Louw dan ook in sy verduideliking van die "vier drade" waaruit die Afrikaner se tradisie bestaan (vgl. Vers. pr. 1, p. 446-449). Dit is nie ' $n$ toevallige ooreenkoms nie, want elders, in die ongepubliseerde 1946-Stellenbosch-lesing, verwoord hy sy "slotsom" waartoe sy besinning oor "oorspronklikheid" hom gelei het, eweneens in terme van die web-beeld: "Ons hele Wes-Europese (en vandag nog wyer) kultuur is 'n eindelose en fyn web. Trek jy op een plek, dan roer die draad baie ver ..." (2.To.14, p. 10). Dat "oorspronklikheid" hiervolgens eerder "oorspronge" beteken - dus die teenoorgestelde van "iets nuuts" - het Van Wyk Louw ook soms deur middel van 'n ander beeld, die wortel-beeld, duidelik gemaak, byvoorbeeld: "Oorspronklikheid = volkome groot menslike kuns / ryk, wyd met sy wortels so ver as dit kan, nie aan 'n tyd gebonde" (2.To.14, p. 12).

Die beelde van die web en wortel beteken dan dat daar by die digter ' $n$ "oopstel aan alle invloede" moet wees (vgl. 2.To.14, p. 22). Daarom is sterk standpunt ingeneem teen Dirk Coster in sy artikel oor die "Jongeren van Zuid-Afrika" in 1936 in De stem (vgl. Kannemeyer, 1990:91 \& 122) en sy inleiding tot Uys Krige se Afrikaanse versameling (1937), wat die Afrikaanse letterkunde wou inperk tot ' $\mathrm{n}$ "eie rigting". Teen beskrywings soos die volgende: " $\mathrm{Zij}$ is zo uitsluitend landelijk ... Z Zij is zo uitsluitend Protestants ..." stel Louw: “'n Groep wat werklik onafhanklik wil wees, moet alles, eenvoudig alles, vir hom as moontlik beskou." (vgl. 2.X.11.1, p. 10-12 en 15). Hiervolgens verklaar hy die begrip "navolging" (epigonisme) as "beïnvloed-word deur 'n te eng kring" (2.To.14, p. 15). "Oorspronklikheid", verkeerdelik gebruik, beteken dan "die beklemtoning van 'n eensydigheid" (2.X.20.15). Om waarlik oorspronklik te wees, behels die volgende opdrag: "stel jou bloot aan alle kragte". Daar mag nie weggeskram word van "invloede" nie - iets waartoe 'n "jong skrywer" geneig is: "Dis vreemd: hoe jonger, hoe minder invloede. Ouer word = altyd meer invloede." Die "oopstel aan alle invloede" beteken dan ook die volgende: "Sodra die volgeling ver wyer as die voorloper word, word dit oorspronklik" (2.To.14, p. 17). Hierdie verklaring van wat ware "oorspronklikheid" dus eindelik is, skakel met wat Van Rensburg (1975:4) aandui as "die sentrale moment in sy (VWL se) intellektuele houding: sy hartstog vir volheid, en, lynreg daarmee verbonde, sy afkeer van eensydigheid" (VR se beklemtoning). 


\subsection{Terugval in die Romantiese opvatting van oorspronklik- heid?}

In die sluitstuk-essay "Klein debat oor oorspronklikheid" verkwalik die kritiese "vriend" vir Louw omdat hy dit so voorgestel het asof die Romantiese opvatting van "oorspronklikheid glad g'n waardevolle iets is nie". Al persoon wat voordeel uit sy beskouing oor "oorspronklikheid" sou kon trek, "is elke digtertjie wat al betrap is dat hy 'afskryf' ... Hierdie epigone - en dis landvol sal uit jou stukkies troos en sterkte haal".

In watter tyd ook al - selfs in ons postmoderne tydsgewrig - word die leserspubliek altyd maar weer onkant gevang wanneer aan die lig kom dat 'n skrywer "afgeskryf" het uit een of ander bron, byvoorbeeld soos onlangs gebeur het met die Adriaan van Dis-debakel (vgl. Britz, 1992 en Hambidge, 1992). Des te skokkender is dit wanneer 'n groot literêre figuur onder verdenking kom. Dink in hierdie verband aan Nijhoff met die openbaarmaking dat die sonnet uit sy "Awater" 'n vertaling van Petrarca se sonnet CCL is. Van Vuuren (1988:83) bring die "Awater"-geval in verband met die resepsie van Tristia: "Dit is opvallend dat Louw van soortgelyke procédé's gebruik gemaak het in Tristia, maar dat geen Afrikaanse kritikus nog die woord 'plagiaat' maar enigsins genoem het in dié verband nie." Sedert Du Plessis (1966:67-73) se ontleding van die "Eusebius"-gedigte waarmee uitdruklik begin is om Louw se funksionele verwerking van 'n oerstofgegewe uit te wys, het 'n stortvloed soortgelyke interpretasies van ander gedigte uit Tristia gevolg.

Die ontdekking van "afskrywing" stuur ook skokgolwe na die skrywer - ongeag of hy die bevoordeelde is. Openbarend is dit om te sien hoe Van Wyk Louw self in 1964 op twee vermeende gevalle van plagiaat van sy tekste gereageer het. Die eerste het sy aanleiding in 'n resensie van sy broer W.E.G. Louw oor Mikro se $T$ in die blou kamer (1963) wat volgens W.E.G. Louw sterk herinner aan Koning-Eenoog (opgevoer in 1960; gepubliseer in 1963). Sy bewering: "Dié invloed strek tot in die woordgebruik", het Mikro hewig laat reageer en het byna tot 'n hofsaak gelei. By nabetragting kon Mikro (1968:170), ná hy aangetoon het hoe hierdie drama uit eie werk van hom ontwikkel het, steeds al geskied dit in die derdepersoonsvorm - met verontwaardiging daaroor skryf: "Om toe van plagiaat beskuldig te word, het hom woedend gemaak." In Van Wyk Louw se brief van 14 Jan. 1964 aan sy broer het dit slegs gegaan om die uitwys van "ooreenkomste" tussen die twee dramas - met geen blyke dat daar ook gekyk is na moontlike verskille met Koning-Eenoog nie. Uit die hele brief is dit duidelik dat Van Wyk Louw sy broer ter wille wou wees - al sou hy ook te kenne gee: "Ek self hanteer nooit invloede nie ...."

In hierdie brief (op p. 2-3) word ook 'n saak van "werklike letterdiefstal" geopper ten opsigte van sy "Beeld van 'n jeug: Duif en perd", waarop hy van 
voomeme was om te reageer. En sy reaksie? Heeltemal in die trant van die Romantiese opvatting van oorspronklikheid deur dit boonop as 'n stuk "opsetlike mistifikasie" (Kannemeyer, 1978:1964) aan te bied. Van Louw se wens in sy brief dat hierdeur "'n voortsetting van die prinsipiële debat" (my beklemtoning) oor oorspronklikheid in Standpunte sou plaasvind, het niks gekom nie. Trouens, deur slegs die datums te kontroleer, kon elke leser al vasstel dat Die perdedief (1960) ná Nuwe verse (1954) verskyn het - waarmee “A.J.C." se grondvraag: "Van Wyk Louw oorspronklik?" heel eenvoudig beantwoordbaar is. En daarmee was die saak van oorspronklikheid opgelos as een "van die onsekerste, vloeibaarste, moeilikste begrippe om te hanteer" (Vers. pr. l, p. 394)!

"Klein debat oor oorspronklikheid" sluit af met die vermaning aan die kritikus om nie "die begrip (oorspronklikheid) wat een van die duistere is, ligvaardig te gebruik nie". En vir die digter vra hy weer om "alleen aan die noodsaaklike (te) dink: 'n goeie stuk werk". Wat beteken hierdie "goeie" ten opsigte van Van Wyk Louw se verklaring van oorspronklikheid?

\subsection{Betekenis van die woorde "gevormde literatuur"}

Die betekenis van die inset van "Ars poetica" ("Uit die gevormde literatuur / is nooit weer poësie te maak nie, / uit die ongevormde wél") kan maklik verkeerd geïnterpreteer word. Hiermee word nié gesê dat intertekstualiteit as sodanig ontken word nie; inteendeel, soos deur die hele Tristia heen word ook hier rekening gehou met die begrip intertekstualiteit. Om te bepaal wat "gevormde literatuur" beteken, sal ook elders, in gepubliseerde én ongepubliseerde vorm, gekyk moet word na die wyse waarop Louw self 'n verklaring vir die verstaan van hierdie woorde verskaf.

In 'n ongepubliseerde stuk, "Navolging, beïnvloeding en oorspronklikheid" (2.AS.O.4, p. 1), wat rondom 1945 ontstaan het, skryf Van Wyk Louw soos volg: "Sou ons nie as 'navolging' in die slegte sin kon noem: 'n te uitsluitend deur literêre werk beïnvloed-word nie? Dit sou neerkom op beïnvloed-word deur wat reeds volkome gevorm is ... ." En in die 1951-lesing voor die Vlaamse Akademie gee Van Wyk Louw aandag aan wat hy noem die "ontlening uit eie werk" (vgl. 2.To.22, p. 12-13). Hy knoop dit aan 'n beroemde vers van Keats, naamlik " $A$ thing of beauty is a joy forever" wat eers "A thing of beauty is a constant joy" geheet het. 5 Hy lewer dan dié kommentaar daarop:

5 Vergelyk in Lojale verset (Vers. pr. 1, bl. 143-144) die verduideliking waarom "A thing of beauty is a joy forever" te verkies is bo die eerste weergawe. 
As dit uit ' $n$ ander digter ontleen was, was dit geen plagiaat of navolging of beinvloeding nie, maar OORSPRONKLIKE SKEPPING. Juis hierdie voorbeeld van 'ontlening uit eie werk', d.w.s. finale kreasie, voer ons tot die hart van ons probleem. Die eerste vaag by elke kunswerk is nie: Was daar tevore iets wat ongeveer dieselfde is nie? Maar is die nuwe werk goed.

Hiervolgens is "volkome gevorm(dheid)", "finale kreasie" en "gevormde literatuur" sinoniem met mekaar - 'n aanname wat vir Van Wyk Louw neerkom op 'n waardebegrip ("goed"/"gaaf"/selfs "groot"). Die "jong digter" moet daarteen waak dat hy nie iets sal doen wat reeds "adekwate vorm" (Vers. pr. 2, p. 426) gevind het nie: "Die grondstof vir jou eie gedagtes sal jy selde vind in dinge wat al volmaakte gestalte gekry het" (Vers. pr. 2, p. 547, my beklemtoning). Dít is om "groot te doen of te misdoen / in die skoene van die grotes" - dus navolging of epigonisme. Om hierdie rede het Van Wyk Louw in 'n radiorede van 1964 (vgl. Vers. pr., p. 535-537) besef dat hy hom as skrywer in sy konfrontasie met die "groot" Shakespeare deeglik sou moes verantwoord:

Wanneer 'n skrywer in die grootmeester alle reeds gegewe elemente van eie wese herken en erken het, bly daar vir hom juis die besluit: "Jy is jy (groot, bewonderd, aanbede, 'on this side idolatry' miskien), máár: ek is ek; ek is ánders." En dan sal hy probeer sorg dat hy geeneen van die meestergrepe met 'n nagevolgde greep wil ewenaar nie.

Boeiend van "Ars poetica" is juis hoe daar afstand verkry word van 'n "grote" in die 20ste eeu, Nijhoff. Dié konfrontasie vind plaas na aanleiding van Nijhoff se invloedryke "fluit"-poëtika. Deur hierdie outeurspoëtika wat in De pen op papier uitgewerk word, toon Nijhoff hom 'n voorstander van die gestaltevers, waarmee hy die ontoereikendheid van die belydenisvers uitwys: "de quaestie is dat gij fluit met uw mond en niet met een fluit. Gij zijt week van inwendige emotie ..." (a.w., p. 17). Daarom dan nog dié vermaning: "Wees voorzichtig, of uw stem schroeit door" (a.w., p. 18).

Kyk ons hiervolgens na strofe 3, merk ons dat ten aanvang gestel word dat daar 'n belıefte is aan 'n "fluit": "Eintlik was 'n fluit nodig". En hierdie "fluit" word gou getransformeer tot 'n "trompet", waardeur dit in die loop van die strofe eindelik apokaliptiese formaat aanneem. Het die gedig hier geëindig, het Louw maar net bevestig wat Nijhoff gesê het van die indrukwekkende mag van sy "fluit"-poëtika: "hebt ge er enig idee van, welk een vrijheid en macht ons een instrument verleent?" (a.w., p. 17). Dit sou dan beteken het dat Louw vir Nijhoff in sy poëtika bloot nagevolg (geïmiteer) het.

In strofe 4 word egter afstand verkry deur al dadelik die gemarkeerde "Maar" met sy dubbelpunt: "Maar: omdat geen fluit voorhande is nie ...". En só stap Louw nie alleen weg van hierdie digter se hoog geroemde poëtika nie, maar 
relativeer hy dit ook deur 'n eie, andersoortige "ars poetica" voor te hou. Hier word gepraat, direk en dringend gepraat, én met die eie mond ("déúr-praat"). Die "déúr" beteken dat die stem deurgaans in beheer bly van die situasie én tot resultate kom, in teenstelling met die verydeling en gevolglike magteloosheid van die stem wat by Nijhoff "door-schroeit" ("wees uiterst voorzichtig, of gij verliest de gehele wereld en wat zij waard is"; a.w., p. 18). En wat bereik Louw nie alles hiermee nie - sónder 'n "fluit". Dit gaan inmmers oor "die skepping van die god", wat uiteraard 'n geweldige "inwendige" beroering in die digter moet meebring. Hy is hierin egter nie "inwendig week van emotie" nie, want die drang na metafisiese klaarheid word deur die dinamiese denke begelei ("déúr-dink"). Deur só, op intertekstuele wyse, al hoe meer afstand van Nijhoff se "fluit"-poëtika ('n soort "gevormde literatuur") te verkry, toon Louw hom in staat om 'n ánder "ars poetica" in eie reg aan te bied. Hiermee het Louw bewys dat die belydenisvers nie per se magteloos is nie.

\section{Teks en interteks}

\subsection{Die teks as teks tussen ander tekste}

Hoewel Van Wyk Louw natuurlik nie die terme teks en interteks gebruik het nie, is daar by hierdie skrywer deurgaans 'n bewustheid van 'n verhouding tussen hierdie twee sake. In hierdie afdeling word kortliks nagegaan hoe Louw oor die verhouding interteks/teks in 'n ongepubliseerde stuk besin het en hoe hy daaraan gestalte gegee het in 'n gedig (uit Tristia). Aan die hand van die beginsels wat ons hieruit kan aflei in aansluiting by die ontleding van "Ars poetica", word dan verder vasgestel hoe Louw se opvatting van oorspronklikheid skakel met bepaalde konsepsies van teksproduksie.

Direk na Van Wyk Louw in die 1944-lesing tot die "slotsom" geraak het dat "ons hele Wes-Europese (en vandag nog wyer) kultuur 'n eindelose en fyn web (is)", kom hy met die vraag: "Wat is dan oorspronklik?" (vgl. 2.To.14, p. 1012).

As eerste antwoord daarop stel hy hoe hy meen dit nié gesien moet word nie: "Ons moet hoegenaamd nie kwantitatief dink nie. Is Shakespeare of Goethe $80 \%$ onoorspronklik en net $20 \%$ oorspronklik? Nee, $100 \%$." Waarom hy dit so sien, motiveer hy soos volg: "Gedagtes of selfs styl is nie besit van iemand nie." Vervolgens oorweeg hy 'n ander beeld, dié van 'n kaleidoskoop om die kulturele "web" mee te verduidelik. Dit laat hom dadelik vra: "Maar is die literatuur dan net 'n eindelose hergroepering van bestaande elemente?" Hiermee is hy dan ook nie tevrede nie, soos blyk uit dié bondige kommentaar: "Troosteloos." As oplossing stel hy hier reeds: "Elke nuwe kunswerk is werklik volkome nuwe lewe." Dan oorweeg hy nog 'n ander beeld om 
"oorspronklikheid" binne die "web" te verklaar. Hy dui dit aan as 'n "beter beeld" wat afkomstig is uit die "biologie", waarvan hy hierdie voorstelling gee: "Eindelose variasies op tema van oë, neus en mond ...". Ná al die gesoek kom Louw tot dié besluit: "Hoofvraag bly: is dit kuns, is dit mooi? Goed, gaaf. Dan sal dit volkome nuut wees."

Hierdie verhouding tussen teks en interteks by Van Wyk Louw word treffend geillustreer deur die kort vers "Ek sal niks sê nie" (uit Tristia). In strofe 1 besef die spreker sy eie nietigheid en onvermoë om iets wesenliks by te dra, want: "Alles wat gesê word, is gesê. / Lank voor ons vól was, / kon iets ons maagdom hê." Hierméé beaam hy ook maar net woorde van ander, dié van Prediker 1: 10: "Is daar iets waarvan 'n mens kan sê: Kyk hier, dit is nuut? Dit was lankal daar in die ou tyd wat voor ons gewees het." Dié toedrag gee aanleiding tot strofe 2 met die besef van troosteloosheid waaruit die mensdom ("ons") nie kan ontsnap nie: "Ons is die herhaling / eindelose desimaal / maling en desimaling". Die punt wat aan die einde van die sin in strofe 2 ontbreek, beklemtoon die voortduur van magteloosheid. Eers wanneer die "ek" in die slotstofe te kenne gee: "ek wil die end haal", vind daar 'n besliste wending plaas - al is dit dan net in die vorm van 'n wens. Deur die "end" te wil "haal", word, soos Kannemeyer (1978:426) die slotvers interpreteer, "iets groots" in die voonuitsig gestel - wat wil sê die moontlikheid van 'n "gevornde" teks op die basis van die gegewens van 'n bepaalde interteks.

Vir Van Wyk Louw is interteks én teks dus van belang. Die teks kom tot stand deur 'n blootstelling aan invloede vanuit ander tekste. Te midde van ander bestaande tekste kry die nuwe teks as "gevormde" wêreld gestalte. Wat hierdie verhouding behels, kan verduidelik word met behulp van 'n passasie uit die essay "Begrip 'oorspronklikheid"' (vers. pr. 2, p. 24):

Die eerste wat ons dan uit die geskiedenis van die literatuur leer, is dat die uiters gespanne strewe na oorspronklikheid self betreklik 'n nuwigheid is; dat dit miskien nie meer as tweehonderd jaar oud is binne die meer as tweeduisend jaar waaroor ons Westerse hiterêre tradisie strek nie; en dat daar lang tydperke is waarin groot literatuur voortgebring is, maar dan tydperke wat byna die teenoorgestelde van oorspronklikheid nagestreef het. Vir hulle was die ideaal nie dat elke skrywer iets moes lewer wat total van alle voorgangers se werk verskil nie, maar eerder dat hy hom so dig as moontlik moes aansluit by die beste wat reeds bekend was (Vers. pr. 2, p. 24, my kursivering).

Die stellingname in die laaste sin beteken dat Van Wyk Louw hom as skrywer van meet af aan blootgestel het aan "invloede". Dit is iets waarvan hy hom voortdurend rekenskap gegee het. So byvoorbeeld in die ongepubliseerde stuk 
van 1940-1941, "Beïnvloeding en die studie van invloede" (2.X.13.5, p. 18), stel hy ten aanvang duidelik dat "beïnvloeding" vir die skrywer "geen passiewe gebeurtenis (in-vloei) is nie"; dit is 'n "uitreik" na ander werke waarmee "gestry" word. Deur hierdie wedywering kom die nuwe werk tot stand. Om dit in terme van "Ars poetica" te stel: Louw knoop hier 'n stryd aan met Nijhoff se formidabele "fluit"-poëtika, waarmee hy wil bewys dat hierdie poëtika nie gelyk het in sy verklaring van die belydenisvers as noodwendig minderwaardig aan die gestaltevers nie. Deur dus uit te gaan van 'n soort "gevormde literatuur", dit nie na te volg nie maar daarmee te stry, kom Louw eindelik tot 'n andersoortige "gevormde literatuur".

Van hierdie soort onwikkelingsgang van die literatuur sê Ibsch (in Bronzwaer e.a., 1977:291): Dit "wordt gezien als een geleidelijke vooruitgang waarbij de componenten imitatio en aemulatio (nabootsing van en wedijver met de als autoriteiten geaccepteerde voorgangers) van belang zijn. In deze conceptie wordt een misschien nooit helemaal bereikbare, doch principieel mogelijke volmaaktheid verondersteld". Dat Van Wyk Louw se besinning binne hierdie kader plaasgevind het, blyk onder andere ook daaruit dat hy die beginsel van vertaling, translatio as die eerste fase in 'n nasionale literatuur se honger na en verowering van die vreemde, so hoog kon aanslaan (vgl. Vers. pr. 2, p. 497498). ${ }^{6}$

Hierdie soort estetiek wat deur Ibsch en andere dan as die Estetiek van Identiteit aangedui word, het by Louw die oorwig in sy verklaring en opvatting van begrippe soos "oorspronklikheid" en "invloed".

Interessant is dit om verder daarop te let dat Louw in 1964 - deur sy voortgesette gemoeidheid met die "vernuwing" in die Afrikaanse prosa - hom enigsins toegeefliker teenoor "oorspronklikheid" in die Romantiese betekenis van hierdie woord begin toon het: 7

6 Vergelyk verder hierdie opmerking van Warners (1956:19) oor die waarde van translatio: "Vertalingen van literaire kunstwerken en van wetenschaplijke geschriften leveren geen nieuwe meesterwerken op, maar kunnen voor de ontwikkeling van een kultuur van enorme betekenis zijn, en oorzaak of aanleiding zijn van het scheppen van nieuwe meesterwerken."

7 "De romantiek breekt definitief met het ideaal van de imitatio. Originaliteit wordt het leidende principe: het werk vindt niet langer meer zijn oorsprong in een normerende verleden, maar is als het ware zijn eigen origine. De figur van het Andere treedt in de plaats van die van Hetzelfde" (Claes, 1988:24). Vergelyk verder Olivier (1992:121-157) se deeghke bespreking van Louw se betrokkenheid 
Die rustelose afwisseling van style, skole 'generasies' - al vinniger, selfs doller, in die moderne tyd - het alleen gedéltelik met modesug en eksperimenteer te doen; die feit wat tot verandering $d$ wing, is die oneindigheid van die lewe, die onbeperktheid van die werklikheid self: geen kunsvorm is in staat om die volle werklikheid uit te druk nie ... (Vers. pr. 2, p. 518).

In sy verwysing na "iets wat nié uit die vroeër bestaande vermoed sou kon geword het nie", praat Louw van 'n "sprong" wat gemaak word. Die verkenning van nuwe, onontgonne werklikhede bring eindelik self dié toegewing mee: "Laat ons nie telkens en altyd vra na afgeronde, volmaakte kunswerke nie" (Vers. pr 2, p. 520). Hiermee was hy op die drumpel van die Estetiek van Teenstelling/Verskil - wat tot ' $n$ veranderde opvatting van oorspronklikheid by Louw sou kon lei! Van hierdie Estetiek sê Ibsch (in Bronzwaer e.a., 1977:292), deur Tynjanov aan te haal, dat dit nie meer gaan "om een planmatige evolutie, maar een sprong, niet om een ontwikkeling, maar een verschuiving".

\subsection{Die teks as interteks van 'n ander teks}

"Ars poetica" is 'n duidelike verklaring en as sodanig die kristallisering van Louw se opvatting van teksproduksie. In sy opmerking dat Louw "behep met 'groot"' is, laat Olivier (1992:181) na om te wys hoe hierdie skrywer se grootheidstrewe deel vorm van die Estetiek van Identiteit. Hierin is Louw nie uniek nie - hoewel Louw natuurlik op 'n persoonlike wyse binne sy sosiohistoriese konteks daaraan uitdrukking gegee het - want soos in Highet se The classical tradition (1967) gesien kan word, is daar deur die eeue heen deur talle skrywers by wyse van wedywering gestrewe na die "volmaakte kunswerk".

In die lig daarvan dat in "Ars poetica" die Estetiek van Identiteit voorop staan, ontstaan die vraag of die intertekstualiteit in hierdie gedig onderskei moet word van dié wat deur Kristeva (1980:66) soos volg beskryf word: "any text is constructed as a mosaic of quotations; any text is the absorption and transformation of another". Of soos deur Lacan gestel met Claes (1977:130) se kommentaar daarby: “'Het woord is geen teken, maar een betekenisknoop'. Waarmee hij (Lacan) bedoelt dat een woord niet betekent door naar de 'werkelijkheid' te verwijzen, maar door zich in te weven in andere, bestaande betekenissen" (my beklemtoning). Die gesprek wat met die Nijhoff-teks in "Ars poetica" gevoer word, beteken dat hierdie oerteks (architeks) by wyse van

by die vernuwing in die Afrikaanse letterkunde. Olivier (1992:123) se aanwending van die begrippepaar "pendule" en "reaksie" kom ooreen met wat in die algemene literatuurwetenskap verstaan word onder "Estetiek van Identiteit" en "Estetiek van Verskil". 
wedywering verbygestreef word deur die eindteks (fenoteks) waartoe gekom word. Het Louw slegs binne hierdie kader gewerk deur telkens suiwer en alleen te strewe na die verkryging van "'n outonome geheel met 'n 'tydlose selfingeslote struktuur van betekenis"' (Degenaar, 1990:4)? Om hierop enigsins antwoord te gee, moet ons 'n gedig in Tristia vind waar die idee van wedywering nie voorop staan nie, dit wil sê waar die gesprek tussen twee tekste self die dominante gegewe is. En om te verseker dat ' $n$ mens jou interpretasie van die gekose gedig nie dwing in die keurslyf van hierdie soort intertekstualiteit nie, is dit wenslik om uit te gaan van 'n bestaande interpretasie waarin nog nie kennis gemaak kon gewees het met die teorie oor intertekstualiteit deur Kristeva en andere nie. Waarop ons in hierdie intertekstuele verhouding dan moet let, kan in die volgende drie punte saamgevat word (vgl. Claes, 1988:48): tekste beteken nie net literêre tekste nie, maar enige soort teks (waarmee wedywering by voorbaat uitgeskakel is); die verskil is net so belangrik en selfs belangriker as die ooreenkoms tussen die tekste; nie net die relasie tussen die tekste is belangrik nie, maar meer nog die funksies wat op die voorgrond geplaas word.

Du Plessis (1966:67-69) se interpretasie van "Keiserlike reskrip" is geskik om aan te toon dat ons by Louw intertekstualiteit aantref wat nie net op die aemulatio-beginsel gebaseer is nie. Hierdie gedigteks verwys na 'n gedeelte uit Eusebius se kerkgeskiedenis, wat beteken dat nie met 'n literêre teks gewedywer word nie. Wat die verskille tussen die twee tekste betref, is daar "die spanning wat ontstaan tussen die hoogs ernstige Eusebiusgeskrif en die ironiese gedig. Die leser raak naamlik bewus van die sterk ooreenkomste en die verskille tussen die aanhaling en die aangehaalde" (Du Plessis, 1966:69). Dat die intertekstuele gesprek afgestem is op 'n bepaalde funksie, blyk weer uit die volgende wat Du Plessis (1966:69) sê: "In die oorgang van Nederlands tot Afrikaans, van wydlopende, baie amptelike prosa tot ironiese vers, gebeur daar soveel dat die leser slegs tot volle waardering van die vers kan kom as hy die gedig langs die Eusebius-gedeelte ... plaas." Indien die leser nie geweet het van die Eusebius-geskrif (die oerteks) nie, sou die ironiese kommentaar van die gedigteks (die eindteks) nie vanself duidelik geword het nie.

Met 'n gedig soos "Keiserlike reskrip" kom dit sterk voor of die streng outonome kunsopvatting laat vaar is. Het Van Wyk Louw hier 'n sprong gemaak van die "werk" (beheer deur die konsep van die skrywer) ná die "teks" (beheer deur die konsep van "netwerk"/intertekstualiteit)? In sy bespreking van Barthes se artikel "From work tot text" (kyk Harari ed., 1980:73-81) sê Harari (1980:39) dat Barthes wegbeweeg het "from that of a formal, complete, organic whole to that of a 'methodological field', a concept whose very premise implies the notion of activity, production, and transformation". Claes (1988:27) verwys 
na hierdie intertekstuele verhouding waar spel en transformasie die botoon voer, as 'n postmoderne estetiek wat hy "de esthetica van het spel" noem.

\section{Samevattend}

Van Wyk Louw se jarelange konfrontasie met oorspronklikheid in die Romantiese sin van die woord kan gesien word in verband met sy afkeer van die homo novus/ die "nuwe", wat wil sê "self-made" mens wat meen dat wat hy bereik het, uit homself voortkom (sien Vers. pr. 2, p. 9-11 en Claes, 1988:35). Dit laat Louw "oorspronklikheid" anders verklaar: as "oorsprong" wat hy in verband sien met sy voorstelling van die web/wortel-beelde om só tot 'n begrip van kulturele verweefdheid te kom. Deur hiermee die belang van die tradisie te beklemtoon, maak Louw onbeskaamd gebruik van "erkende vorms" wat hy ontgin en tot herlewing roep - byvoorbeeld die tradisionele balladevorm en laat-Middeleeuese sinnespelvorm in onderskeidelik Gestaltes en diere (1942) en Berei in die woestyn (1968). Sy "oopstel aan alle invloede" wat noodwendig 'n méérstemmigheid meebring, het hom reeds iets van die wese van die postmoderne intertekstualiteit laat begryp nog voor die teoretisering daaroor 'n aanvang geneem het.

\section{Literatuurlys}

Barthes, Roland. 1980. From work to text. In: Harari, Josué V. (ed.) Textual strategies. London : Methuen. p. 73-81.

Britz, Etienne. 1992. Van Dis se beweerde plagiaat opgelos. Beeld: Nov. 16. Bronzwaer, W.J.M., Fokkema, D.W. \& Ibsch, E. 1977. Tekstboek algemene literatuurwetenschap. Baarn : Amboboeken.

Claes, Paul. 1977. Intertextualiteit. Streven: 126-134, Nov.

Claes, Paul. 1988. Echo's echo's. Amsterdam : De Bezige Bij. C., A.J. 1964. Van Wyk Louw oorspronklik? Standpunte, 17(4):64-66.

Degenaar, J.J. 1990. Intertekstualiteit. In: Malan, Charles \& Jooste, G.J. (reds.) Onder andere. Pretoria : Universiteit van Suid-Afrika. p. 3-12.

Dekker, Gerrit. 1926. Die invloed van Keats en Shelley in Nederland gedurende die negentiende eeu. Groningen : Wolters.

Dokumentasiesentrum. 1988. Katalogus van dokumente in die N.P. van Wyk Louw-versameling. Universiteitsbiblioteek, Stellenbosch.

Du Plessis, P.G. 1966. Aantekeninge by vier "Eusebius"-gedigte. Standpunte, 19(5):67-73.

Hambidge, Joan. 1989. Die parodie as stylfiguur. Tydskrif vir Letterkunde, 26(4):54-60.

Hambidge, Joan. 1992. Etienne Britz, Van Dis en 'Blame it on postmodernism!' Beeld: Des. 10.

Harari, Josué V. (ed.) 1980. Textual strategies. London : Methuen. 
Hesse, Walter. 1953. Gevaartekens vir die Afrikaanse poësie. Tydskrif vir Letterkunde, 3(2):17-41.

Highet, Gilbert. 1967. The classical tradition. London : Oxford University Press.

Kannemeyer, J.C. 1978. Geskiedenis van die Afrikaanse literatuur I. Kaapstad : Academica.

Kannemeyer, J.C. 1990. Die dokumente van Dertig. Kenwyn : Jutalit.

Krige, Uys (opst.) 1937. Afrikaanse versameling. Inleiding deur Dirk Coster. Maastricht : Stols.

Kristeva, Julia. 1980. Desire in language. New York : Columbia University Press.

Louw, N.P. van Wyk. 1951. Klein debat oor oorspronklikheid. Die Huisgenoot: 19, Des. 14.

Louw, N.P. van Wyk. 1962. Tristia. Kaapstad : Human \& Rousseau.

Louw, N.P. van Wyk. 1963. "Vernuwing" en "gehalte" - 'n Paar anti-kritiese aantekeninge. Standpunte, 16(3):27-33.

Louw, N.P. van Wyk. 1986. Versamelde prosa 1/2. Kaapstad : Tafelberg / Human \& Rousseau.

Louw, W.E.G. 1942. Die invloed van Gorter op Leopold. Kaapstad : Nasionale Pers.

Louw, W.E.G. 1963. T in die blou kamer - Te min speserye in dié Kerspoeding? Die Burger: Des 13.

Mikro. 1968. Hy koop toe vir hom 'n pen. Johannesburg: Voortrekkerpers.

Mulder, H.A. 1937. Oor invloed in die literatuur. Jaarboek van die Afrikaanse Skrywerskring: 57-64.

Nijhoff, M. s.j. De pen op papier. Amsterdam : Salm.

Olivier, Gerrit. 1992. N.P. van Wyk Louw: literatuur, filosofie, politiek. Kaapstad : Human \& Rousseau.

Rombauts, W. \& Hoebeke, W. 1986. De Koninklijke Academie voor Nederlandse Taal- en Letterkunde (1886-1986). Gent : Secretariaat voor de Koninklijke Academie.

Rosteutscher, J.H.W. 1941. N.P. van Wyk Louw en Stefan George. Ons eie boek, 7(3):115-122.

Van Rensburg, F.I.J. 1975. Swewende ewewig. Kaapstad: Tafelberg.

Van Vuuren, Helize. 1988. "Awater" as modemistiese teks. Tydskrif vir Letterkunde, 36(1):75-83.

Warners, J.D.P. 1956-1957. Translatio - imitatio - aemulatio. De Nieuwe Taalgids, 49: 19-25; 49:82-88; 50:193-201. 